\title{
Implementasi Pembentukan Karakter Bersahabat Melalui Model Pembelajaran Group Investigation
}

\author{
H.M. ZAINUDDIN \\ Jurusan KSDP, Fakultas IImu Pendidikan, Universitas Negeri Malang \\ email: hm_zainuddin@yahoo.com
}

\begin{abstract}
The result of the observation in an elemtaray school in Blitar, 2012 is as follows: the teachers' presentation is not interesting; the students are not given a chance to develop their idea and mind; the students get boring with the learning, the concepts given to the students are given separately, and their grades are below the minimum of the criteria passing grade. The research problems: the application of Group Investigation learning model improves student learning outcomes; and the application of 'Group Investigation' learning model shapes friendly character / communicative. The result of the research shows that Group Investigation model runs smoothly and The students' learning outcome increases.
\end{abstract}

Keywords: Implementation, friendly character, Group Investigation

\begin{abstract}
ABSTRAK: Hasil observasi di SDN Blitar, 2012 sebagai berikut: penyajian guru tidak menarik; siswa kurang diberi kesempatan mengembangkan ide dan pikirannya; siswa merasa bosan; konsep yang disampaikan kepada siswa terpisah-pisah; dan nilai dibawah Kriteria Ketuntasan Minimal. Masalah penelitian: penerapan model pembelajaran 'Group Investigation' dapat meningkatkan hasil belajar, dan penerapan model pembelajaran 'Group Investigation' dapat membentuk karakter bersahabat/ komunikatif. Hasil penelitian, Penerapan pembelajaran 'Group Investigation' berjalan lancar dan Hasil belajar meningkat.
\end{abstract}

Kata Kunci: Implementasi, karakter bersahabat, Group Investigation

\section{Pendahuluan}

Hasil observasi awal peneliti terhadap guru kelas VSDN J ingglong 01Kabupaten Blitar, pada tanggal 18 September 2012.Peneliti memperoleh hasil bahwa pembelajaran IPS yang berlangsung di SDN J ingglong 01 Kabupaten Blitar mengalami beberapa permasalahan, di antaranya: (1) mata pelajaran IPS disajikan oleh guru sebagai mata pelajaran yang tidak menarik, karena pembelajaran berpusat pada guru; (2) siswa kurang diberi kesempatan dalam mengembangkan ide dan pikirannya sehingga pembelajaran tidak bermakna bagi siswa; (3) siswa merasa bosan dengan apa yang dipelajari karena siswa hanya menghafalkan konsep-konsep yang disampaikan dalam pembelajaran; (4) konsep-konsep yang disampaikan kepada siswa diberikan terpisahpisah; (5) siswa mudah lupa apa yang sudah diingat sebelumnya karena pembelajaran terbatas pada kegiatan membaca buku atau mendengar penjelasan; dan (6) rendahnya hasil belajar IPS dengan nilai di bawah Kriteria Ketuntasan Minimal (KKM).

IPS merupakan pelajaran yang cukup komprehensif untuk menyikapi dan memecahkan masalah-masalah sosio kebangsaan di Indonesia, sesuai dengan kadar kemampuan dan tingkat perkembangan peserta didik (Somantri, M. Numan, 2001: 23). Berdasarkan pendapat Somantri mata pelajaran IPS, mestinya lebih bersifat edukatif ketimbang akademis. Terkait dengan itu maka rumusan tujuan pembelajaran IPS telah memenuhi aspek-aspek yang menjadi sasaran dari sebuah proses pendidikan dan pembelajaran. IPS mengkaji seperangkat peristiwa, fakta, konsep, dan generalisasi yang berkaitan dengan isu sosial. Oleh karena itu, IPS dapat dikatakan sebagai studi mengenai perpaduan antara ilmu-ilmu dalam rumpun ilmu-ilmu sosial dan juga humaniora untuk melahirkan pelakupelaku sosial yang dapat berpartisipasi dalam memecahkan masalah-masalah sosio-kebangsaan. Bahan kajiannya menyangkut peristiwa, 
seperangkat fakta, konsep dan generalisasi yang berkait dengan isu-isu aktual, gejala dan masalahmasalah atau realitas sosial serta potensi daerah.

Tantangan seorang guru adalah bagaimana merumuskan suatu metode pembelajaran yang disesuaikan dengan kondisi dan suasana siswa agar proses pembelajaran dapat berhasil dengan baik dan mencapai tujuan. Metode yang digunakan seorang guru dalam proses pembelajaran akan sangat menentukan hasil dari proses pembelajaran tersebut. Berdasarkan permasalahan tersebut, maka diperlukan sebuah pembelajaran yang dilaksanakan dalam konteks otentik, memberikan kesempatan pada siswa untuk mengerjakan tugas bermakna, memberikan pengalaman bermakna, dilaksanakan melalui kerja kelompok, mengutamakan kebersamaan, dan dilaksanakan secara menyenangkan. Salah satu model pembelajaran yang memiliki karakteristik tersebut di atas adalah Model Group Investigation (GI). Kasihani (2009:18). Mendesain model pembelajaran GI menjadi enam tahapan, yaitu (1) Tahap mengidentifikasi topik dan pengelompokan. Para siswa memilih berbagai sub topik dalam suatu wilayah masalah umum yang biasanya digambarkan lebih dahulu oleh guru. Para siswa selanjutnya diorganisasikan menjadi kelompokkelompok yang berorientasi pada tugas (task oriented groups) yang beranggotakan dua hingga enam orang. Komposisi kelompok pada pembelajaran ini heterogen baik dalam jenis kelamin, etnik, maupun kemampuan akademik; (2) Tahap merencanakan penyelidikan kelompok. Para siswa beserta guru merencanakan berbagai prosedur belajar khusus, tugas dan tujuan umum yang konsisten dengan topik dan subtopik yang telah dipilih; (3) Tahap melaksanakan penyelidikan. Para siswa melaksanakan rencana yang telah dirumuskan. Pembelajaran harus melibatkan berbagai aktivitas dan keterampilan dengan variasi yang luas dan mendorong para siswa untuk menggunakan berbagai sumber, baik yang terdapat di dalam maupun di luar sekolah. Guru secara terus-menerus mengikuti kemajuan tiap kelompok dan memberikan bantuan jika deperlukan; (4) Tahap menyiapkan laporan akhir. Para siswa menganalisis dan mensintesis berbagai informasi yang diperoleh pada langkah tiga dan merencanakan agar dapat diringkaskan dalam suatu penyajian yang menarik di depan kelas; (5) Tahap menyajikan laporan. Semua kelompok menyajikan suatu presentasi yang menarik dari berbagai topik yang telah dipelajari agar siswa dalam kelas saling terlibat dan mencapai suatu perspektif yang luas mengenai topik tersebut; (6) Tahap evaluasi. Guru beserta siswa melakukan evaluasi mengenai kontribusi tiap kelompok terhadap pekerjaan kelas sebagai suatu keseluruhan. Evaluasi dapat mencakup tiap siswa secara individu atau kelompok dan bahkan keduaduanya.

Jenis penelitian yang digunakan adalah Penelitian Tindakan Kelas (PTK). "Penelitian Tindakan Kelas (PTK) adalah suatu penelitian tindakan (action research) yang dilakukan oleh guru yang sekaligus sebagai peneliti di kelasnya atau bersama-sama dengan orang lain (kolaborator) dengan jalan merancang, melaksanakanatau tindakan, mengobservasi dan merefleksikan tindakan secara kolaboratif dan partispatif yang bertujuan untuk memperbaiki atau meningkatkan mutu (kualitas) pembelajaran di kelas melalui suatu tindakan tertentu dalam suatu siklus." (Kunandar, 2008: 45).

Desain penelitian yang digunakan mengacu pada model Kemmis dan M.C. Taggart (Arikunto, 2009: 16) yang terdiri dari 4 komponen yaitu: perencanaan, tindakan, observasi, dan refleksi.

Pada penelitian dengan pendekatan kualitatif, peran peneliti dalam pelaksanaan penelitian adalah sebagai bagian utama. Peneliti merupakan perencana, pelaksana, pengumpul data, penganalisis data, dan pada akhirnya peneliti menjadi pelapor hasil penelitian dan dibantu guru mitra.Peneliti sangat berperan dalam keseluruhan penelitian, sehingga kehadiran peneliti di lapangan adalah mutlak. Hal ini sesuai dengan ciri-ciri dari penelitian kualitatif, yaitu manusia (peneliti) bertindak sebagai instrumen penelitian.

Kancah Penelitian adalah SDN Jingglong 01Kabupaten Blitar yang beralamat di JI. Mawar Indah, Kelurahan Jingglong Kecamatan Sutojayan Kabupaten Blitar tahun pelajaran 2012/2013. Sekolah ini memiliki ruang kelas sejumlah 6 kelas, satu laboratorium Multimedia, satu ruang perpustakaan, satu ruang UKS, satu ruang komputer, satu ruang guru, satu ruang kepala sekolah, dan satu kantin sekolah. Jumlah personel SDN J ingglong 01 Kabupaten Blitar terdiri dari 14 personel dengan klasifikasi, guru sejumlah 13 orang, dan satu penjaga sekolah. Jumlah siswa secara keseluruhan adalah 202 siswa dibagi menjadi 6 kelas. SDN J ingglong 01 menjadi fokus penelitian karena mempertimbangkan berbagai hal, diantaranya model pembelajaran IPS masih konvensional tanpa memperhatikan terbentuknya pembiasaan sikap sesuai norma pancasila dan hal tersebut sangat berpengaruh terhadap konsep IPS dan perilaku siswa.

Subjek penelitian adalah siswa SDN J ingglong 01Kabupaten Blitar. Siswa yang menjadi fokus penelitian adalah siswa kelas $\mathrm{V}$ tahun pelajaran 2012/2013 sebanyak 33 siswa yang terdiri dari 13 siswa laki-laki dan 20 siswa perempuan.

Data yang dikumpulkan dalam penelitian ini berupa (1) nilai hasil yang berupa lembar kerja siswa (LKS) pada setiap pertemuan dan tes akhir 
pada tiap siklus, dan (2) hasil observasi aktivitas siswa dan guru, serta dokumentasi berupa Rencana Pelaksanaan Pembelajaran (RPP), format penilaian lembar kerja siswa (LKS), format penilaian tes akhir pembelajaran, catatan lapangan, garfik yang menunjukkan terbentuknya karakter Bersahabat/Komunikatif pada setiap kegiatan pembelajaran dengan menerapkan model pembelajaran Group Investigation. Sumber data dan sekaligus sebagai subjek penelitian adalah siswa kelas VSDN Jingglong 01 yang mengikuti kegiatan pembelajaran.

\section{Pembelajaran Model Group I nvestigation}

Observasi pada siklus I ini dilaksanakan selama kegiatan pembelajaran berlangsung. Kegiatan pembelajaran ini dilaksanakan dalam dua pertemuan dengan masing-masing pertemuan adalah tiga jam pelajaran. Pertemuan I dilaksanakan pada hari Sabtu, 29 September 2012, dan pertemuan II dilaksanakan pada hariSenin tanggal 1 Oktober 2012. Peneliti melakukan pengamatan dengan lembar observasi.

Secara umum peneliti menilai bahwa pelaksanaan pembelajaran sudah cukup baik, meskipun masih terlihat adanya kekurangan. Kekurangan yang tampak adalah sebagian siswa masih tidak terbiasa belajar dengan model pembelajaran Group Investigation, sehingga peneliti terkadang harus mengulangi untuk menjelaskan masing-masing tahap model Group Investigation di setiap kelompok yang berbeda. Hal ini juga ditunjukkan dengan sering munculnya pertanyaan dari siswa ketika peneliti berkeliling memantau kerja kelompok siswa. Sementara itu, kegiatan kelompok dinilai juga belum berjalan dengan baik karena siswa tidak terbiasa dengan kelompok campuran (laki-laki dan perempuan dalam satu kelompok). Siswa pria atau wanita yang kebetulan menjadi satu-satunya dalam kelompok biasanya merasa tidak percaya diri sehingga mereka memilih untuk tidak ikut berpartisipasi dalam diskusi kelompok. Selain itu, pada beberapa kelompok sempat terlihat hanya anggota kelompok yang dianggap paling pintar yang mengerjakan tugas dari peneliti.

Proses pembelajaran juga menunjukkan hanya beberapa siswa yang aktif. Hal tersebut terlihat ketika peneliti memberikan soal mencongak, dari beberapa kesempatan yang diisi peneliti dengan pemberian soal secara mencongak ini terlihat siswa yang sama yang berani untuk mencoba memberikan jawaban. Hal ini juga terlihat saat peneliti memulai pelajaran, hanya beberapa siswa yang dapat dengan cepat menangkap apa yang disampaikan peneliti.

Selama pelaksanaan pembelajaran, observer memberikan catatan lapangan sebagaimana pada Tabel 1. Observasi terhadap hasil belajar siswa di ukur melalui hasil pengerjaan tes akhir siklus. Tes I ini dilaksanakan pada hari

Tabel 1

Ringkasan Catatan Lapangan

\begin{tabular}{|c|c|c|}
\hline $\begin{array}{l}\text { Pertemuan } \\
\text { ke- }\end{array}$ & Observer & Catatan Lapangan \\
\hline 1 & 1 & $\begin{array}{l}\text { Pembelajaran cukup menyenangkan. } \\
\text { Siswa tampak aktif mengikuti kegiatan pembelajaran } \\
\text { Penggunaan waktu sudah cukup efektif. } \\
\text { Siswa belum bekerjasama dengan baik dalam kelompok } \\
\text { Karakter Bersahabat/Komunikatif yang diharapkan muncul pada KBM } \\
\text { belum tampak. } \\
\text { Guru masih banyak membantu }\end{array}$ \\
\hline 2 & 1 & $\begin{array}{l}\text { Pembelajaran cukup menyenangkan, siswa aktif dan guru juga cukup } \\
\text { kreatif dalam memberikan bimbingan pada tiap tahapan model Group } \\
\text { Investigation. } \\
\text { Guru telah memberikan reward bagi yang aktif dalam pembelajaran, } \\
\text { namun kurang (belum tampak) dalam memberikan penguatan secara } \\
\text { verbal } \\
\text { Siswa sudah lebih bisa bekerja kelompok tetapi masih perlu bantuan } \\
\text { guru. } \\
\text { Karakter Bersahabat/Komunikatif dalam KBM sedikit lebih muncul } \\
\text { dengan adanya teguran dari guru untuk saling bekerjasama dan } \\
\text { menjadi tutor sebaya. }\end{array}$ \\
\hline
\end{tabular}

Sumber: Hasil Observasi Guru dan Siswa 
H.M.ZAINUDDIN Implementasi Pembentukan Karakter Bersahabat Melalui Model Pembelajaran Group ...

Selasa tanggal 2 Oktober 2012. Tes ini merupakan tes akhir dari pelaksanaan siklus I. Hasil dari tes I ini secara ringkas dapat disajikan dalam tabel berikut.

\section{Hasil Pengerjaan Tes I}

\section{Tes I}

Banyak siswa

Siswa yang tuntas belajar 21

Siswa yang belum tuntas belajar 12

Sumber: Hasil Tes Siswa

Dari tabel di atas terlihat bahwa 21 atau $63,63 \%$ siswa telah mampu memenuhi kriteria keberhasilan belajar yang telah ditetapkan sebelumnya. Sementara sisanya, 12 atau 36,36\% siswa, belum memenuhi kriteriakeberhasilan belajar.

Salah satu hal yang berpengaruh pada hasil ini adalah siswa kehilangan cukup banyak waktu karena proses Group Investigation yang memakan cukup banyak waktu, sehingga siswa dalam mengerjakan tes terkesan tergesa gesa. Selain itu, ada gangguan dari kelas lain yang istirahat lebih awal. Peneliti dan observer sudah berusaha mengatasi hal ini (gangguan dari luar), tetapi yang dilakukan tidak mampu memberikan perbaikan yang baik. Dengan demikian 63,63\% siswa belum memenuhi kriteria keberhasilan belajar, sehingga akan dilakukan perbaikan pembelajaran pada siklus II.

\section{Siklus II}

Sama seperti tindakan I, observasi dalam penelitian ini dilakukan selama kegiatan pembelajaran berlangsung. Kegiatan pembelajaran dilaksanakan dalam dua pertemuan dengan masing-masing pertemuan adalah tiga jam pelajaran. Pertemuan I dilaksanakan pada hari Rabu tanggal 3 Oktober 2012, dan pertemuan II dilaksanakan pada hari Kamis tanggal 4 Oktober 2012. Observer melakukan pengamatan berdasarkan lembar observasi yang disediakan oleh penulis.

Secara umum, observer menilai bahwa pelaksanaan pembelajaran sudah sangat baik. Kekurangan yang ada pada siklus I telah berhasil diperbaiki pada siklus II. Siswa sudah terbiasa dengan kelompok campuran (laki-laki dan perempuan dalam satu kelompok). Hal ini terlihat dari kerjasama yang ditunjukkan oleh setiap anggota kelompok. Setiap ada diskusi kelompok mereka bekerjasama dengan baik untuk menjadi yang pertama menyelesaikan tugas dari peneliti. Selain itu juga sudah tidak terlihat anggota kelompok yang dianggap paling pintar yang bekerja sendiri. Mereka juga semakin terlihat terbiasa untuk bertanya kepada sesama anggota kelompok bila ada hal yang tidak mengerti, belajar dengan bantuan media, juga belajar dengan tahap-tahap pada model pembelajaran Group Investigation.

Selama pelaksanaan pembelajaran, observer memberikan catatan lapangan sebagaimana pada Tabel 2. Observasi terhadap hasil belajar siswa di ukur melalui hasil pengerjaan tes akhir siklus. Tes II ini dilaksanakan pada hari J umat tanggal 5 Oktober 2012. Tes ini merupakan tes akhir dari pelaksanaan siklus II. Hasil dari tes II ini secara ringkas dapat disajikan dalam halaman berikut.

Tabel 2

Ringkasan Catatan Lapangan Siklus I I

\begin{tabular}{|c|c|c|}
\hline $\begin{array}{l}\text { Pertemuan } \\
\text { ke- }\end{array}$ & Observer & Catatan Lapangan \\
\hline 1 & 1 & $\begin{array}{l}\text { Kegiatan kelompok sudah lancar } \\
\text { Guru sudah memberikan penguatan secara verbal } \\
\text { Siswa dapat bekerjasama dengan anggota kelompoknya yang lain } \\
\text { Guru sudah tidak terlalu membantu siswa } \\
\text { Kegiatan pembelajaran sudah cukup efektif } \\
\text { Siswa sangat antusias belajar dan mulai mengurangi kecenderungan } \\
\text { bertanya pada guru } \\
\text { Diskusi kelompok sudah baik } \\
\text { Guru hanya mengamati dan sangat sedikit memberi bantuan pada } \\
\text { siswa. }\end{array}$ \\
\hline
\end{tabular}

Sumber: Hasil Observasi Guru dan Siswa 


\section{Hasil Pengerjaan Tes I I}

\begin{tabular}{lc}
\hline Tes I & Banyak siswa \\
\hline Siswa yang tuntas belajar & 28 \\
Siswa yang belum tuntas belajar & 5
\end{tabular}

Sumber: Hasil Tes Siswa

Dari tabel di atas terlihat bahwa 28 atau $84,84 \%$ siswa telah mampu memenuhi kriteria keberhasilan belajar yang telah ditetapkan sebelumnya. Sementara sisanya, 5 atau 15,15\% siswa, belum memenuhi kriteriakeberhasilan belajar. Dengan demikian, hasil ini telah mampu memenuhi kriteria keberhasilan belajar yang ditetapkan. Sehingga penelitian ini tidak dilanjutkan pada tindakan yang berikutnya.

Selama dilakukan penelitian, baik tindakan I maupun tindakan II, peneliti mencatat beberapa temuan penelitian sebagai berikut. (1) Siswa tidak terbiasa dengan kelompok campuran (kelompok yang terdiri dari laki-laki dan perempuan), sehingga pada siklus I siswa kurang dapat memaksimalkan kegiatan diskusi kelompok; (2) Pada siklus II siswa telah dapat lebih mengoptimalkan diskusi kelompok, sehingga kegiatan pembelajaran yang dilakukan mampu memberikan kesempatan kepada siswa untuk mengembangkan aspek Bersahabat/Komunikatif dan penemuan informasi dari berbagai sumber dengan lebih baik; (3) Siswa lebih menyukai belajar dengan model pembelajaran Group Investigation dalam kegiatan belajarnya; (4) Siswa akan mudah belajar jika diberikan sedikit materi di awal kegiatan kemudian dilanjutkan dengan latihan keterampilan; (5) Siswa lebih termotivasi untuk belajar jika diberikan penguatan baik secara lisan, tulisan maupun pemberian hadiah.

Temuan pada kegiatan pembelajaran di siklus I pertemuan 1 dan 2 menunjukkan bahwa pembelajaran yang dilakukan dengan model pembelajaran Group Investigation sudah berjalan dengan cukup baik. Pembelajaran IPS menggunakan model pembelajaran Group Investigation ini dilaksanakan dengan tahapan mengidentifikasi topik dan pengelompokan, merencanakan penyelidikan kelompok, melaksanakan penyelidikan, menyiapkan laporan akhir, menyajikan laporan, evaluasi.

Pada tahap eksplorasi, guru bertanya dengan pertanyaan yang mengantarkan siswa mengidentifikasi topik dan pengelompokan permasalahan yang sesuai dengan materi dan dibuat rencana penyelidikan kelompok. Siswa dibimbing untuk menggali kembali pengetahuan yang telah mereka miliki sebelumnya yang terkait dengan materi yang akan dipelajari. Proses pembelajaran dilakukan dengan diskusi kelas dan tanya jawab. Pada tahap ini siswa sering melakukan kesalahan dalam memberikan jawaban. Kegiatan ini sesuai dengan pendapat Hudojo(2005:119) bahwa keterampilan didasarkan pada pemahaman dan latihan yang cukup. Hal ini karena siswa kurang cermat dalam memahami soal yang diberikan oleh peneliti, disamping siswa juga kurang dapat menggali kembali materi yang pernah dipelajari sebelumnya. Selain itu sebagian besar siswa masih bergantung kepada peran guru, sehingga pada saat proses pembelajaran mereka terlihat pasif.

Pada tahap selanjutnya, tahap elaborasi dilaksanakan kegiatan yang sesuai dengan tahap dalam model Group Investigation, yaitu Tahap melaksanakan penyelidikan, Tahapmenyiapkan laporan akhir, dan Tahap menyajikan laporan. Pada tahap pertama yaitu Tahap melaksanakan penyelidikan, peneliti membimbing siswa untuk melaksanakan langkah kerja yang telah disusun oleh guru, mengingat Group Investigation yang diberikan merupakan Group Investigation yang tidak sepenuhnya murni melainkan terbimbing. Siswa dengan antusias membaca langkah kerja dan berusaha melaksanakan langkah kerja. Peneliti terlebih dahulu membagikan Lembar Kegiatan (LK) yang berisi langkah penyelidikan tentang bentuk pembagian waktu di Indonesia.

Selanjutnya, siswa mendapatkan sumber informasi berupa bahan bacaan yang berisi bentuk pembagian waktu di Indonesia. Pada saat kegiatan ini berlangsung, siswa tidak mengalamai kesulitan berarti karena materi ini sangat mudah dipahami siswa. Pertanyaan khusus (pendalaman materi) dapat dijawab dengan mudah oleh siswa. Setelah guru memberikan pertanyaan, salah satu siswa diminta untuk menjelaskan jawabannya. Peneliti kemudian meminta siswa tersebut untuk menjelaskan kepada siswa lain yang masih mengalami kesulitan, siswa sudah tidakmalu memberikan penjelasan pada temannya (bersahabat/komunikatif) dan diperjelas oleh peneliti.

Tahap berikutnya adalah Tahap menyiapkan laporan akhir.Pada tahap ini, guru membimbing siswa menghimpun data yang berasal dari jawaban siswa. Jawaban tersebut dihimpun menjadi beberapa pernyataaan yang dipersempit, sehingga data yang terkumpul tidak melebar kemana-mana, tetapi tetap dalam satu lingkup permasalahan utama. Hal ini sesuai dengan pendapat Wina Sanjaya(2007: 201-205) yaitu "Mengumpulkan data adalah aktivitas menjaring informasi yang dibutuhkan untuk menguji hipotesis yang diajukan. Dalam model pembelajaran ini mengumpulkan data merupakan proses mental yang sangat penting dalam pengembangan intelektual. Tugas dan peran guru dalam tahapan ini adalah mengajukan pertanyaan-pertanyaan 
yang dapat mendorong siswa untuk berpikir mencari informasi yang dibutuhkan."

Tahap selanjutnya adalah Tahap menyajikan laporan. Dalam hal ini Jawabanjawaban yang sudah terhimpun, didiskusikan dan disesuaikan dengan sumber yang benar. Saat siswa bersama dengan kelompoknya untuk menganalisis, peneliti berkeliling untuk memeriksa hasil analisis siswa serta memberikan bimbingan kepada kelompok yang mengalami kesulitan. Pada kegiatan ini, peneliti mendapati sebagian besar kelompok sudah menyelesaikan analisis, sehingga peneliti kemudian meminta kelompok yang sudah selesai menjadi fasilitator bagi teman kelompok lain, pada saat itu dipantau dengan catatan lapangan bagaimana perkembangan karakter "Bersahabat/Komunikatif." Sesuai dengan pendapat Wina Sanjaya (2007: 201-205) yaitu "Artinya, kebenaran jawaban yang diberikan bukan hanya berdasarkan argumentasi, akan tetapi harus didukung oleh data yang ditemukan dan dapat dipertanggungjawabkan."

Keseluruhan siklus menyatakan bahwa semua kelompok menyampaikan kesimpulannya dengan bahasa kelompoknya, dan selanjutnya dipadatkan oleh guru dalam bahasa yang sederhana dan mudah diterima oleh siswa dan dicatat di buku catatan masing-masing. Hal ini diperkuat dengan pendapat Sanjaya (2007: 201 - 205) yaitu “untuk mencapai kesimpulan yang akurat sebaiknya guru mampu menunjukkan pada siswa data mana yang relevan."

Pada tahap terakhir, tahap konfirmasi, siswa diuji pengetahuannya tentang apa yang telah mereka pelajari pada hari itu. Siswa diberikan soal secara mencongak dengan harapan bahwa siswa tidak merasa terbebani dengan pengerjaan soal yang selalu menggunakan pensil dan kertas, serta untuk menghemat waktu. Kegiatan ini sesuai dengan pendapat Hudojo (2005: 120) bahwa aktivitas latihan yang efektif sangat menghemat waktu dengan syarat asalkan bahannya bermakna bagi siswa.

Temuan pada siklus I pertemuan 1 dan 2 mendasari tindak lanjut yang akan dilakukan pada siklus II dilakukan dengan terlebih dahulu melakukan perbaikan pada rencana pembelajaran, yaitu dengan berusaha mengoptimalkan kegiatan diskusi, penyempurnaan tahap dalam model pembelajaran Group Investigation, serta pemberian penguatan baik berupa lisan, tulisan, maupun pemberian hadiah atas keberhasilan siswa dalam menjawab pertanyaan. Selain itu, akan dioptimalkan pendampingan yang dilakukan oleh peneliti. Seperti halnya siklus I, kegiatan pada siklus II ini, dilaksanakan dengan tahap eksplorasi, elaborasi, serta konfirmasi yang memuat langkah dalam model pembelajaran Group Investigation.

Pada tahap eksplorasi, siswa dibimbing untukmengidentifikasi topik dan pengelompokan permasalahan yang sesuai dengan materi dan dibuat rencana penyelidikan kelompok. Pembelajaran dilakukan dengan tanya jawab dan diskusi kelas. Siswa dibimbing untuk mengingat kembali materi pada siklus I dengan pertanyaanpertanyaan yang diberikan secara mencongak. Selanjutnya, tahap elaborasi, dilaksanakan kegiatan Tahap melaksanakan penyelidikan, Tahap menyiapkan laporan akhir, dan Tahap menyajikan laporan.

Secara umum penjelasan masing-masing tahap sama dengan siklus I, namun pada siklus II, sebagian besar kegiatan dilakukan dengan diskusi secara berkelompok. Pembelajaran dengan diskusi kelompok dilakukan dalam kelompok kecil yang heterogen dengan tujuan untuk memaksimalkan proses pembelajaran. Hal ini sesuai dengan pendapat Sapriya (2009: 8) bahwa banyaknya anggota kelompok yang relatif kecil dalam kelompok akan membuat siswa aman mengemukakan pendapat dan temuan-temuannya dibandingkan dalam 1 kelas. Selain itu pada tahap ini peneliti juga melakukan pendampingan terhadap diskusi yang dilakukan oleh siswa.

Tahap terakhir dari kegiatan ini adalah konfirmasi. Pada tahap ini, siswa diuji kembali pengetahuannya tentang materi yang baru saja dipelajari. Siswa diberikan soal secara mencongak. Siswa yang berhasil menjawab pertanyaan dengan benar diberikan penghargaan berupa pujian dan tepuk tangan dari siswa yang lain. Sementara dua siswa yang berhasil menjawab benar soal cerita yang diberikan oleh peneliti diberikan penghargaan berupa hadiah. Hal ini sesuai dengan pemikiran Hudojo(1988:138139) yang menyatakan bahwa salah satu teknik pertanyaan yang dapat diberikan adalah teknik bertanya untuk penguatan baik itu secara verbal maupun secara non-verbal. Teknik bertanya penguatan secara verbal merupakan motivasi agar peserta didik bertindak sesuai dengan apa yang kita kehendaki, serta untuk mengembangkan ide atau jawaban dari peserta didik itu sendiri. Biasanya diberikan dalam ucapan atau kata-kata pujian terhadap keberhasilan siswa. Sedangkan teknik bertanya penguatan nonverbal biasanya dilakukan dengan memberikan isyarat seperti anggukan, senyuman atau mengacungkan ibu jari. Dengan penguatan yang tepat, maka siswa merasa mendapatkan penghargaan atas apa yang sudah dilakukan. Dari penghargaan tersebut akan menambah motivasi untuk menyelesaikan setiap permasalahan dengan tepat. Selain penghargaan karena siswa dapat menjawab dengan tepat, penghargaan juga diberikan kepada seluruh siswa yang telah bekerjasama dengan baik. Hal ini merupakan indikasi berkembangnya karakter bersahabat/komunikatif pada siswa sejalan 
dengan tujuan model pembelajaran Group Investigation yaitu mengembangkan kreatif dan inovasi serta kerjasama yang baik dari seluruh kelompok.

\section{Model “Group I nvestigation" dapat Meningkatkan Hasil belajar}

Hasil belajar menunjukkan ketuntasan belajar yang diperoleh pada siklus I adalah $63,63 \%$. Hasil ini menunjukkan bahwa pembelajaran yang dilakukan belum dapat memenuhi kriteria ketuntasan belajar yang telah ditetapkan, sehingga dilanjutkan pada siklus II.Sedangkan pembelajaran pada siklus II, secara umum telah berjalan sesuai dengan yang diharapkan. Pembelajaran pada siklus II memberikan ketuntasan belajar $84,84 \%$ atau dibulatkan $85 \%$. Hal ini menunjukkan bahwa pembelajaran tersebut telah mampu memenuhi kriteria ketuntasan belajar yang telah ditetapkan sebelumnya, yaitu $85 \%$. Dengan demikian, kegiatan pembelajaran dengan model pembelajaran Group Investigation memberikan hasil yang meningkat pada siklus II. Hal ini sesuai dengan keterangan tahap-tahap Penelitian Tindakan Kelas menurut Kemmis \& McTaggart (dalam Arikunto, 2006:97) yaitu Tahap penelitian tindakan kelas di atas dilampaui secara siklus. Masing-masing siklus tiga kali pertemuan. Pada siklus pertama dibuat rencana tindakan, dilanjutkan dengan pelaksanaan, observasi dan refleksi. Pelaksanaan siklus pertama dapat berlanjut pada tahap kedua jika ketuntasan siswa pada siklus pertama mencapai 70 . Siklus akan berhenti hingga ketuntasan siswa pada siklus tertentu mencapai skor 85.

Nilai rata-rata siswa pada siklus II meningkat lebih dari 75 dan ketuntasannya mencapai $84,84 \%$ atau dibulatkan $85 \%$, hal ini memberi makna bahwa pembelajaran IPS telah mencapai ketuntasan dan selesai pada siklus II sesuai dengan keterangan alur Penelitian Tindakan Kelas tersebut.

\section{Model "Group I nvestigation" Dapat Membentuk Karakter siswa}

Secara umum, pembelajaran pada siklus I yang terdiri dari dua pertemuan telah berjalan dengan cukup baik. Dari segi proses yang menitikberatkan pada ketercapaian tahap-tahap pembelajaran model Group Investigation yang terintegrasi dengan karakter bersahabat/ komunikatif, ini sejalan Mimbar. Vol XXVII, No. 1 (Juni 2011): 47-55 penerapan konsep kerja sama dan pengaturan diri dalam pembelajaran merupakan faktor terpenting dalam membangun komunikasi dan persahabatan. Hal ini memberikan perubahan aspek afektif siswa terutama kerjasama tanpa membeda-bedakan baik dari segi kualitas maupun kuantitas antar siswa. Pemahaman siswa akan pentingnya sumber informasi yang mendukung analisa data dan kesimpulan, sudah mulai muncul pada siklus I dan II. Hal ini memperkuat ketuntasan secara afektif khususnya peningkatan karakter bersahabat/komunikatif. Bersahabat/Komunikatif ditunjukkan dengan sikap atau tindakan yang selalu ingin memberi bantuan pada orang lain yang membutuhkan. (Zainuddin, 2012: 39). Mimbar, Vol. XXVI, No.2. (Desember 2010): 123-134 kelompok teman sebaya dengan misdemeanors (perilaku melanggar aturan) di sekolah cenderung kurang bersahabat, hal ini harus dihindari.Untuk itu Perlu bantuan pada temannya, siswa sudah berupaya saling bekerjasama, Bersahabat/ Komunikatif pada anggota kelompoknya, siswa menghargai guru, dan mau melaksanakan langkah-langkah model Group Investigation yang sudah dipersiapkan guru. Hal ini sesuai pendapat menurut Foerster (dalam Zainuddin, 2012), bahwa "Karakter merupakan sesuatu yang mengualifikasi seorang pribadi, karakter menjadi identitas yang mengatasi pengalaman kontingen yang selalu berubah, dari kematangan karakter inilah, kualitas seorang pribadi diukur."

\section{Simpulan dan Saran}

Penerapan model pembelajaran Group Investigation pada pembelajaran IPS tentang keragaman kenampakan alam dan pembagian waktu di Indonesia di kelas V SDN Jingglong 01 Kabupaten Blitar memberikan kontribusi yang baik terhadap kemampuan siswa. Kemampuan yang baik ini mendukung aspek kognitif dan afektif siswa khususnya pembentukan karakter bersahabat/ komunikatif yang diimplementasikan dengan kerjasama antar siswa pada tahap-tahap model pembelajaran Group Investigation.

Hasil belajar IPS dengan model pembelajaran Group Investigation di kelas VSDN J ingglong 01Kabupaten Blitar dapat meningkat dengan memberikan hasil ketuntasan belajar $(63,63 \%)$ sebutan cukup pada siklus I dan $(84,84 \%)$ sebutan baik pada siklus II. Berdasarkan hasil penelitian tersebut, maka pembelajaran menggunakan model pembelajaran Group Investigation dapat membantu meningkatkan hasil belajar siswa kelas VSDN Jingglong 01 .

Penerapan pembelajaran Group Investigation dapat membentuk karakter Bersahabat/ Komunikatif menjadi lebih baik. Indikasinya siswa saling membantu kepada teman yang membutuhkan, menolong teman yang meminta bantuan.

Artikel ini dapat memberikan acuan untuk penelitian lanjutan, sehingga peneliti lebih berinovatif untuk melakukan penelitian yang serupa 
H.M.ZAINUDDIN Implementasi Pembentukan Karakter Bersahabat Melalui Model Pembelajaran Group ...

ataupun penelitian lain yang masih berkaitan dengan penelitian yang sudah dilakukan ini.

Disisi lain guru diharapkan lebih terampil dalam melaksanakan tahap-tahap pembelajaran model Group Investigation. Pihak yang berwenang memberikan manajemen dan administrator sekolah, terutama kepala sekolah lebih merekomendasikan kepada gurunya untuk melaksanakan penelitian dalam meningkatkan kinerjanya, khususnya pada pembelajaran bidang studi IPS di lembaga yang dipimpinnya.

Guru yang berperan dalam proses pembelajaran hendaknya menerapkan model pembelajaran Group Investigation agar membantu pembentukkan karakter bersahabat dan peningkatan hasil belajar siswa.

\section{DAFTAR RUJ UKAN}

Arikunto, S. (2009). Penelitian Tindakan Kelas. Jakarta: Bumi Aksara.

BSNP. (2007). Kurikulum Tingkat Satuan Pendidikan: Mata Pelajaran IPS Tingkat SD. Jakarta: Departemen Pendidikan Nasional.

Gulo (2005). Strategi Belajar Mengajar. Jakarta: Grasindo.

Hamalik, O. (2007). Proses Belajar Mengajar. J akarta: Bumi Aksara

Hudojo, H. (1988). Belajar dan Pembelajaran. Malang: IKIP Malang

J oyce, B., and Weil, M. (1996). Models of Teaching. Boston: Allyn and Bacon.

Kasihani. (2009). Model-model Pembelajaran. Malang: Universitas Negeri Malang.

Kunandar. (2008). Langkah Mudah Penelitian Tindakan Kelas untuk Meningkatkan Kinerja Guru dan Dosen. Jakarta: Remaja Rosdakarya.

Mulyasa, E. (2003). Kurikulum Berbasis Kompetensi, Karakteristik, dan Implementasinya. Bandung:
PT. Remaja Rosdakarya.

Mulyasa, E. (2007). Menjadi Guru Profesional (Menciptakan Pembelajaran Kreatif dan Menyenangkan). Bandung: PT. Remaja Rosdakarya.

Sanjaya, W. (2007). Strategi Pembelajaran (Berorientasi Standar Proses Pendidikan). Jakarta: Prenada Media Group.

Sapriya. (2009). Pendidikan IPS Konsep dan Pembelajaran. Bandung: Remaja Rosda Karya.

Setiono, L. (2012). Model Pembelajaran Tujuh Bintang. (Online), (http://lilik setiono/ wordpress.com/2012/08/12), diakses 24 J anuari 2011.

Somantri, M.N. (2001). Menggagas Pembaharuan Pendidikan IPS. Bandung.

Sukmadinata, N.S.(2009). Metode Penelitian Pendidikan. Bandung: Penerbit: PT. Remaja Rosda Karya.

Supriya. (2009). Pendidikan IPS: Konsep dan Pembelajaran. Bandung: PT Remaja Rosda karya offset.

Suyanto, K.K.E. (2008). Model Pembelajaran. Malang: Universitas Negeri Malang.

Trianto. (2007). Model-model Pembelajaran Inovatif Berorientasi Konstruktivistik: Konsep Landasan Teoritis - Praktis dan Implementasinya. J akarta: Prestasi Pustaka Publisher.

Uno, B.H. (2007). Model Pembelajaran (Menciptakan Proses Belajar Mengajar yang Kreatif dan Efektif). Jakarta: PT. Bumi Aksara.

Winataputra, U.S. (2008). Materi dan Pembelajaran IPS SD. Jakarta: Universitas Terbuka.

Zainuddin, M. (2012). Membentuk karakter anak melalui pendidikan IPS. Malang: UM Press.

Zainuddin. Mimbar, Vol. XXVII, No.1 (Juni): 47-55ol. "Terakreditasi"SK Dikti No.64a/DIKTI/Kep/241. 